\title{
The importance of extracellular antigens in Pseudomonas cepacia infections
}

\author{
D.C.STRAUS, D.E.WOODS*, MIRIAM K. LONON and C.W. GARNER†
}

Departments of Microbiology and †Biochemistry, Texas Tech University Health Sciences Center, Lubbock, Texas 79430, USA, and "Department of Microbiology and Infectious Diseases, The University of Calgary Health Science Centre, Calgary, Alberta, Canada

\begin{abstract}
Summary. A clinical isolate of Pseudomonas cepacia from a cystic fibrosis patient was examined for its ability to produce extracellular toxic material. The organism was grown to stationary phase in a defined medium and toxic material was isolated by ultrafiltration, ion-exchange chromatography on DEAE-Sephacel and gel-filtration chromatography on Sepharose 4B. It consisted of a surface carbohydrate antigen, lipopolysaccharide and protein, and had an LD50 (when injected intraperitoneally into mice) of $395 \pm 20 \mu \mathrm{g}$. The toxicity appeared to be associated with the lipopolysaccharide portion of the complex, because boiling for $15 \mathrm{~min}$ and exposure to proteolytic enzymes had no effect on toxicity. However, saponification destroyed the toxicity of the compound. Studies employing radial immunodiffusion with the sera of mice infected with this organism demonstrated production of the complex in vivo at levels approaching those sufficient to produce death. When sublethal amounts of this complex were placed in the lungs of specific-pathogen-free rats, the lung pathology observed after $12,24,36$ and $48 \mathrm{~h}$ was extensive. However, antibody generated in rabbits against this material could protect mice against the complex, as well as against challenge by the homologous organism. These data indicate that extracellular toxic material produced by $P$. cepacia may be responsible for the lethality and lung tissue destruction normally associated with an active pneumonia caused by this organism.
\end{abstract}

\section{Introduction}

Pseudomonas cepacia, originally characterised as the cause of soft rot of onion bulbs, is now considered an important opportunist pathogen in compromised individuals, particularly in hospitals (Burkholder, 1950). While many patients colonised by $P$. cepacia apparently suffer no ill effects, other individuals experience severe life-threatening manifestations such as pneumonia, bacteraemia and meningitis (Goldman and Klinger, 1986). Cystic fibrosis (CF) centres across the USA demonstrate that CF patients are at especially high risk of colonisation and infection (Rosenstein and Hall, 1980; Corey et al., 1984; Isles et al., 1984; Tablan et al., 1985; Thomassen et al., 1985, 1986) and are currently the largest group suffering from the consequences of $P$. cepacia exposure (Goldman and Klinger, 1986). This finding is of considerable importance because of cases of fulminant necrotis-

Received 17 Aug. 1987; accepted 8 Dec. 1987. ing pneumonia and bacteraemia in this population (Isles et al., 1984; Thomassen et al., 1985). Treatment of $\boldsymbol{P}$. cepacia infections in CF patients is particularly difficult, because the organism is resistant to a wide range of antimicrobial compounds (Goldman and Klinger, 1986).

$P$. cepacia-associated pulmonary disease in $\mathrm{CF}$ patients was first described after examining aminoglycoside resistance in pseudomonads isolated from sputa (Blessing et al., 1979). This study reported a $4 \% P$. cepacia colonisation rate in CF patients between 1974 and 1978. By 1981, rates were reported to be as high as $18 \%$ in a study in Toronto (Isles et al., 1984). An increase in P. cepacia colonisation from $5 \cdot 1 \%$ in 1979 to $20 \%$ in 1983 was also reported (Thomassen et al., 1986). However, these workers reported a decrease in isolation and mortality due to $P$. cepacia once patients carrying $P$. cepacia were isolated from those not colonised by the organism.

The emergence of $P$. cepacia in CF patients is particularly alarming because colonisation with 
this organism is often associated with rapid clinical deterioration. For example, Isles et al. (1984) reported that patients infected with $P$. cepacia had greater impairment of pulmonary function than those infected with $P$. aeruginosa. This syndrome was characterised by high fever, severe progressive respiratory failure, leucocytosis, an elevated erythrocyte sedimentation rate and a $62 \%$ fatality rate. Upon autopsy of these patients, histological examination of the lung showed severe necrotising pneumonia. Thomassen et al. (1985) also reported that CF patients colonised with $P$. aeruginosa followed by $P$. cepacia appeared to have more serious lung involvement and a poorer prognosis than those patients colonised with $P$. aeruginosa alone. Furthermore, there was a recent report of four female patients who showed leucocytosis, high fever and mortality following $P$. cepacia colonisation (Boxerbaum and Klinger, 1984). Interestingly, this organism was isolated from the blood of all four patients. This is of considerable importance because $P$. aeruginosa, which colonises the vast majority of CF patients, generally does not cause bacteraemia in this population (McCarthy et al., 1980). Recently, Tablan et al. (1987) showed that $P$. cepacia most of ten affected patients with moderate or advanced CF and this was usually associated with an adverse clinical outcome.

Such cases of death and severe necrotising pneumonia led us to speculate that there is an extracellular toxic substance produced by $P$. cepacia that is responsible for lethality and extensive lung pathology. Relatively little is known about the virulence properties of $P$. cepacia. McKevitt and Woods (1984) examined $48 P$. cepacia CF isolates and found that $88 \%$ were protease-positive; $69 \%$ of these strains produced lipase, but no exotoxin A or exoenzyme $\mathrm{S}$ activity was detected. Lonon et al. (1987) have recently demonstrated the production of lipolytic activity against a variety of substrates by $10 \mathrm{CF}$ clinical isolates of $P$. cepacia.

In this study we describe an extracellular toxic complex (ETC) produced by $P$. cepacia that appears to be responsible for the lethality and extensive pulmonary necrosis associated with lung infections caused by this organism.

\section{Materials and methods}

\section{Bacteria, bacterial virulence and media}

The strains employed in these studies were $P$. cepacia $61 \mathrm{~g}$ and K30-6. P. cepacia $61 \mathrm{~g}$, from the sputum of a patient with CF, was kindly supplied by J.D. Klinger, Rainbow Babies and Children's Hospital, Cleveland,
$\mathrm{OH}$, USA. $P$. cepacia $\mathrm{K} 30-6$, also isolated from the sputum of a CF patient, was kindly supplied by C.L. Prober, The Hospital for Sick Children, Toronto, Ontario, Canada. Both strains were serotyped by a typing scheme based on whole-cell antigen agglutination (McKevitt $e t$ al., 1987). P. cepacia $61 \mathrm{~g}$ is a serotype $\mathrm{D}$ organism and $P$. cepacia $\mathrm{K} 30-6$ is serotype $A$. The bacteria were maintained frozen in Trypticase Soy Broth and glycerol $20 \%$ $\mathrm{v} / \mathrm{v}$ at $-70^{\circ} \mathrm{C}$. Liquid cultures were grown in Anwar's chemically defined medium consisting of $3 \mathrm{mM} \mathrm{NaCl}$, $12 \mathrm{mM}\left(\mathrm{NH}_{4}\right)_{2} \mathrm{SO}_{4}, 3.2 \mathrm{mM} \mathrm{MgSO} 4,1.2 \mathrm{mM} \mathrm{K}_{2} \mathrm{HPO}_{4}$, $0.02 \mathrm{mM} \mathrm{FeSO}_{4}$, and $20 \mathrm{~mm}$ glucose in $50 \mathrm{~mm} 3-(\mathrm{N}-$ morpholino) propanesulphonic acid (MOPS; Sigma Chemical Company, St Louis, MO, USA), pH 7.4 (Anwar et al., 1983b). Lethality was determined by injecting graded numbers of the organism intraperitoneally (i.p.) into Swiss-Webster white mice and calculating the LD50 value by the method of Reed and Muench (1938).

\section{Purification of the ETC}

Cultures were grown in 10-L quantities of Anwar's medium for $96 \mathrm{~h}$ at $37^{\circ} \mathrm{C}$ in a shaker adjusted to $200 \mathrm{rpm}$. The bacteria were pelleted at $17000 \mathrm{~g}$ at $4^{\circ} \mathrm{C}$ for $60 \mathrm{~min}$, and the supernatant fluids were concentrated by ultrafiltration to a volume of $100 \mathrm{ml}$ on an Amicon DC-2 concentrator (Amicon Corp., Danvers, MA, USA) with a H1P30-43 hollow-fiber filter that retains substances with a mol. wt $>30000$. Remaining supernatant fluids were lyophilised. This material was dissolved in $50 \mathrm{ml}$ of $0.01 \mathrm{M}$ Tris-hydrochloride buffer $(\mathrm{pH} \mathrm{8.0)}$ ) and dialysed overnight against $16 \mathrm{~L}$ of the same buffer at $4^{\circ} \mathrm{C}$. The dialysate was then placed on a DEAE-Sephacel (Pharmacia Fine Chemicals, Inc., Piscataway, NJ, USA) column $(2.5 \times 40 \mathrm{~cm})$ which had been equilibrated overnight at $4^{\circ} \mathrm{C}$ with $0.01 \mathrm{M}$ Tris-hydrochloride buffer, $\mathrm{pH} 8 \cdot 0$. The column was washed with two bed volumes of the starting buffer, and the absorbing material was eluted with a linear $\mathrm{NaCl}(0-1.0 \mathrm{M})$ gradient in the starting buffer. The eluant was monitored for protein at $280 \mathrm{~nm}$ with a flow-through 2138 Uvicord S monitor (LKB Instruments, Inc., Rockville, MD, USA) and recorded by a 6520 -S chopper bar six-channel recorder (LKB Instruments). Fractions of 100 drops each (approximately $4.2 \mathrm{ml}$ ) were collected. In addition, the column eluate was monitored for total hexose, uronic acids and ketodeoxyoctonate (KDO) as follows. Every fifth fraction was concentrated to dryness by lyophilisation and $1.0 \mathrm{ml}$ of deionised distilled water was added to each tube. A $0 \cdot 2-\mathrm{ml}$ sample was assayed for uronic acid by the procedure of Blumenkrantz and Asboe-Hansen (1973), with glucoronic acid (sodium salt; Sigma) as the standard. A $0.5-\mathrm{ml}$ sample was assayed for total hexose by the anthrone procedure (Loewus, 1952). Finally, a $0 \cdot 2-\mathrm{ml}$ sample was assayed for KDO by the method of Osborn (1963) employing Escherichia coli O55:B5 LPS (Sigma) or KDO (Sigma) as the standard. The various peaks were pooled, lyophilised and dialysed against $0.01 \mathrm{M}$ Trishydrochloride buffer $(\mathrm{pH} \mathrm{8.0)}$ ). Pools that were lethal for mice after i.p. injection were further purified on Sepharose 
4B in the following way. Less than $100 \mathrm{mg}$ of the ETC in $8 \mathrm{ml}$ of $0.01 \mathrm{M}$ Tris-hydrochloride buffer $(\mathrm{pH} \mathrm{8.0)}$ was applied to an ascending-flow column $(2.5 \times 90 \mathrm{~cm})$ of Sepharose $4 \mathrm{~B}$ at $4^{\circ} \mathrm{C}$. Fractions ( 100 drops) were collected (approximately $4.5 \mathrm{ml}$ ) and protein peaks were monitored at $280 \mathrm{~nm}$ and recorded. Every fifth fraction was additionally monitored for uronic acid (Blumenkrantz and Asboe-Hansen, 1973), KDO (Osborn, 1963), and total hexose (Loewus, 1952). The appropriate fractions were pooled, lyophilised, and then dialysed against the $0.01 \mathrm{M}$ Tris-hydrochloride buffer $(\mathrm{pH} 8.0)$. The pool that was toxic for mice represented the purified ETC and was used for chemical characterisation as well as LD50 determination and pulmonary necrosis studies.

\section{Chemical characterisation of ETC}

The purified ETC was assayed for protein by the procedure of Lowry et al. (1951) with bovine serum albumin (fraction V; Sigma) as the standard, for KDO by the procedure of Osborn (1963), and for total hexose by the anthrone procedure (Loewus, 1952). In KDO assays, E. coli O55: B5 LPS (Sigma) or KDO (Sigma) was the standard. In anthrone assays, glucose and mannose (Sigma) were standards.

To determine which portion of the ETC was responsible for its toxicity, $10 \mathrm{mg}$ of the material was boiled for 15 min or exposed to bovine pancreas trypsin type I (Sigma; crystallised twice, ethanol-precipitated, and substantially salt-free) $1 \mathrm{~g} / \mathrm{L}$ for $30 \mathrm{~min}$ at $25^{\circ} \mathrm{C}$. To saponify the ETC, $c .1 \mathrm{~g} / \mathrm{L}$ in deionised distilled water was brought to $1 \mathrm{~N}$ with $10 \mathrm{~N} \mathrm{NaOH}$ in a screw-capped tube and heated at $66^{\circ} \mathrm{C}$ for $18 \mathrm{~h}$. This material was then neutralised with concentrated $\mathrm{HCl}$ and examined for toxicity in mice. The fatty-acid analysis of ETC was performed on fatty acid methyl esters, prepared with boron trifluoride in methanol, after acid or base hydrolysis as described by Rietschel et al. (1972). A Varian Model 3300 gas chromatography equipped with a $12-\mathrm{m}$ capillary column coated with SE-30 and a flame ionisation detector was used to detect the fatty acids. The analysis was performed with temperature programming from $150^{\circ}$ to $250^{\circ} \mathrm{C}$, increasing at a rate of $4^{\circ} \mathrm{C} / \mathrm{min}$ after an initial isothermal period of $4 \mathrm{~min}$. Fatty-acid standards were obtained from Supelco, Inc. Identification of each fatty acid was made by comparison of retention times with those of standards from plots of the log of the retention times versus chain length and from comparison of retention times with standards obtained with a $30-\mathrm{m}$ capillary column coated with SP-2330 held at $180^{\circ} \mathrm{C}$. Hydroxy fatty acids were not analysed on this column.

\section{Virulence studies in mice}

The LD50 values of the ETC were determined by injecting $1-\mathrm{ml}$ amounts in $0.01 \mathrm{M}$ Tris-hydrochloride buffer, $\mathrm{pH} \mathrm{8.0,} \mathrm{i.p.} \mathrm{into} \mathrm{Swiss-Webster} \mathrm{mice.} \mathrm{After}$ observation for 72-h, dead mice were counted and LD50 values were calculated by the method of Reed and
Muench (1938). Before injection of the ETC preparation into mice, it was sterilised by exposure to UV irradiation $\left(100 \mu \mathrm{W} / \mathrm{cm}^{2}\right.$ at room temperature for $\left.30 \mathrm{~min}\right)$. The final ETC preparation was streaked on Trypticase Soy Agar (BBL Microbiology Systems, Cockeysville, MD, USA) plates for confirmation of sterility. For the virulence studies in mice, $0.1 \mathrm{ml}$ of the ETC in $0.01 \mathrm{M}$ Tris buffer, pH 8.0, were injected i.p., simultaneously with the bacteria into Swiss-Webster mice weighing $20-25 \mathrm{~g}$. Control animals received the bacterial dilutions along with $0 \cdot 1 \mathrm{ml}$ of $0.01 \mathrm{~m}$ Tris- $\mathrm{HCl}$ buffer, $\mathrm{pH} 8 \cdot 0$.

\section{Quantitation of in-vivo production of the ETC and Ouchterlony analysis of DEAE-Sephacel pools I and II}

Radial immunodiffusion studies were performed to quantify the ETC found in the serum of infected mice that had received $10 \mathrm{LD} 50$ of $P$. cepacia $61 \mathrm{~g}$. Fifteen mice were inoculated i.p. with $P$. cepacia $61 \mathrm{~g}$ and observed for 24-48 h. When the animals appeared to be near death, they were exsanguinated by cardiac puncture. The amount of ETC in their sera was measured by radial immunodiffusion as follows. A $0.85 \%$ agarose solution in borate buffer was heated to boiling and allowed to cool to $50^{\circ} \mathrm{C} ; 750 \mu \mathrm{l}$ of homologous antiserum against the ETC was then added to $15 \mathrm{ml}$ of the agarose suspension and poured on to a $3 \frac{1}{4} \times 4$ in. $(c .8 .1 \times 10 \mathrm{~cm})$ glass plate and allowed to solidify. The antiserum was prepared in New Zealand white rabbits by one subcutaneous injection of $500 \mu \mathrm{g}$ of ETC in complete Freund's adjuvant and three subcutaneous injections of $500 \mu \mathrm{g}$ of ETC in incomplete Freund's adjuvant, each spaced a week apart. The plates were incubated for $24 \mathrm{~h}$ at room temperature, and the zone diameters of the precipitin reactions within the gel were measured and compared with known quantities of ETC tested in the same manner. Five mice were also inoculated i.p. with 10 LD50 values of heat-killed (boiled for $15 \mathrm{~min}$ ) $P$. cepacia $61 \mathrm{~g}$ as a control. The rabbit serum generated against purified ETC was employed to examine the antigenic relationship between DEAE-Sephacel pool II and purified ETC by double immunodiffusion in agar gels. These gels were prepared with Ionagar No. 2 (Oxoid) $1 \%$ in borate-buffered saline $(0.02 \mathrm{M}, \mathrm{pH} 8 \cdot 0)$.

\section{Pseudomomas cepacia inoculation}

Twenty male Sprague-Dawley rats (specific pathogenfree, $200-220 \mathrm{~g}$ in weight, Charles River, Canada, Inc., St Constant, Quebec) were tracheostomised under ether anaesthesia and $0.05 \mathrm{ml}$ of a suspension of $P$. cepacia $61 \mathrm{~g}$, embedded in agar beads as previously described (Cash et al., 1979), was placed in a distal bronchus in the left lobe with a bead-tipped curved needle. After inoculation, animals were housed in wire-bottom cages, and food and water were given ad libidum. Ten and 20 days after inoculation, 10 animals were exsanguinated by cardiac puncture under anaesthesia. The lungs of the remaining five animals were processed for bacterial quantitation as previously described (Cash et al., 1979). 


\section{ETC inoculation}

Eight male Sprague-Dawley rats were tracheostomised under ether anaesthesia, and $0.05 \mathrm{ml}$ of a sterile suspension of ETC $(50 \mu \mathrm{g})$ was placed in a distal bronchus in the left lobe with a bead-tipped curved needle. Eight control rats were inoculated in the same manner with $0.05 \mathrm{ml}$ of sterile PBS. After inoculation, animals were treated as for $P$. cepacia inoculation. At $12,24,36,48 \mathrm{~h}$ after inoculation, two animals from each group were exsanguinated by cardiac puncture under anaesthesia. The lungs were prepared for histological examination as previously described (Cash et al., 1979).

\section{Animal protection studies}

Antiserum to the purified ETC was prepared in New Zealand white rabbits by one subcutaneous injection of $500 \mu \mathrm{g}$ of ETC in complete Freund's adjuvant and three subcutaneous injections of $500 \mu \mathrm{g}$ of ETC in incomplete Freund's adjuvant, each spaced a week apart. To test the protective ability of this antiserum against purified ETC and homologous live $P$. cepacia, the following protocols were followed. Five mg of purified ETC in $5 \mathrm{ml}$ of $0.01 \mathrm{M}$ Tris buffer, $\mathrm{pH} 8.0$, was placed in a beaker with $0.5 \mathrm{ml}$ of rabbit anti-ETC (IRS). Five $\mathrm{mg}$ of purified ETC in $5 \mathrm{ml}$ of $0.01 \mathrm{M}$ Tris buffer, $\mathrm{pH} 8.0$, was placed in a beaker with $0.5 \mathrm{ml}$ of normal rabbit serum (NRS). Both beakers were stirred at room temperature for $1 \mathrm{~h}$. After this time, $500 \mu \mathrm{g}$ of ETC + NRS and $500 \mu \mathrm{g}$ of ETC + IRS were injected i.p. into Swiss-Webster mice.

To determine if anti-ETC antibody would protect experimental animals against live homologous $P$. cepacia, the following protocol was followed. $P$. cepacia $61 \mathrm{~g}$ was grown to the stationary phase $\left(\mathrm{OD}_{540}=1.0\right)$ in Anwar's defined media. For every $5 \mathrm{ml}$ of washed P. cepacia $61 \mathrm{~g}$ added to a beaker, $1.0 \mathrm{ml}$ of IRS was also added. The same amount of washed bacteria was added to a beaker containing $1.0 \mathrm{ml}$ of NRS for every $5 \mathrm{ml}$ of bacteria. The beakers were incubated with stirring at room temperature for $1 \mathrm{~h}$. Then $c$. 10 LD50 of $P$. cepacia $61 \mathrm{~g}$ from each beaker was injected i.p. into Swiss-Webster mice. Deaths were recorded in both groups for 5 days.

To test the ability of the carbohydrate surface antigen (pool II from the DEAE-Sephacel column) prepared from $P$. cepacia $61 \mathrm{~g}$ to protect mice against challenge with live $P$. cepacia, the following protocol was followed. On days 1 and 8 , each of 20 Swiss-Webster mice was immunised i.p. with $100 \mu \mathrm{g}$ of pool II from the DEAE-Sephacel column in $1 \mathrm{ml}$ of phosphate buffered saline (PBS), and each of another 20 Swiss-Webster mice received $1 \mathrm{ml}$ of PBS i.p. On day 15,10 of the pool II-immunised mice and 10 of the PBS control mice were inoculated i.p. with $1 \times 10^{9}$ cfu of the homologous $P$. cepacia $61 \mathrm{~g}$ strain. On day 15,10 of the pool II-immunised mice and 10 of the PBS control mice were inoculated i.p. with $1 \times 10^{9} \mathrm{cfu}$ of a heterologous $P$. cepacia strain K30-6. Deaths were recorded in all groups for 3 days.

\section{Results}

\section{Purification of the ETC and the non-toxic surface antigen}

When $1 \mathrm{ml}$ (c. $1 \mathrm{mg}$ dry weight) of the ultrafiltration concentrated supernate from $10 \mathrm{~L}$ was injected i.p. into 10 Swiss-Webster mice, all 10 animals were dead within $48 \mathrm{~h}$. Control animals (10) that received uninoculated media treated in the same manner suffered no ill effects, indicating that some form of toxic material was elaborated by $P$. cepacia $61 \mathrm{~g}$.

The elution profile of the extracellular material produced by $P$. cepacia $61 \mathrm{~g}$ on DEAE-Sephacel can be seen in fig. 1. This material could be separated into two distinct uronic acid-containing pools $\left(\mathrm{OD}_{520}\right)$ by DEAE-Sephacel chromatography. Ouchterlony analysis with rabbit antiserum produced against purified ETC (DEAE-Sephacel pool I) gave a line of identity between DEAESephacel pool I and II, with pool I showing a spur that was not present in pool II (data not shown). Pool I represented the material that bound to the ion-exchange resin and eluted between 0.10 and $0.45 \mathrm{M} \mathrm{NaCl}$. Only pool I contained KDO-positive material $\left(\mathrm{OD}_{548}\right)$ and was toxic for Swiss-Webster mice. Because DEAE-Sephacel pool II was not toxic for mice and appeared to be mostly carbohydrate, it was referred to as the carbohydrate surface antigen.

When animals were inoculated i.p. with $1 \mathrm{ml}$ of pool I (c. $0.7 \mathrm{mg}$, dry weight), all mice died in $48 \mathrm{~h}$. Pool I was lyophilised, dialysed to remove salt, dissolved in $8 \mathrm{ml}$ of $0.01 \mathrm{M}$ Tris-hydrochloride

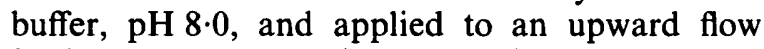
Sepharose 4B column $(2.5 \times 90 \mathrm{~cm})$. The eluate was monitored as was done for the DEAE-Sephacel column. The elution profile of DEAE-Sephacel pool I on Sepharose 4B is shown in fig. 2. This material could be fractionated by Sepharose 4B into two distinct pools on the basis of absorption at $280 \mathrm{~nm}$. When material from these two pools was injected i.p. into Swiss-Webster mice, only pool-I material (void volume material) was toxic. The purified ETC was found to be approximately $3 \%$ protein. The LD50 value for this material injected i.p. into 20-25 g Swiss-Webster mice was calculated to be $395 \pm 20 \mu \mathrm{g}$. The average time to death for ETC injected animals was $36 \mathrm{~h}$.

\section{Presence of KDO in biologically active LPS preparations from $P$. cepacia}

We have used the method of Osborn (1963) to assay culture supernate from $P$. cepacia $61 \mathrm{~g}$ and 


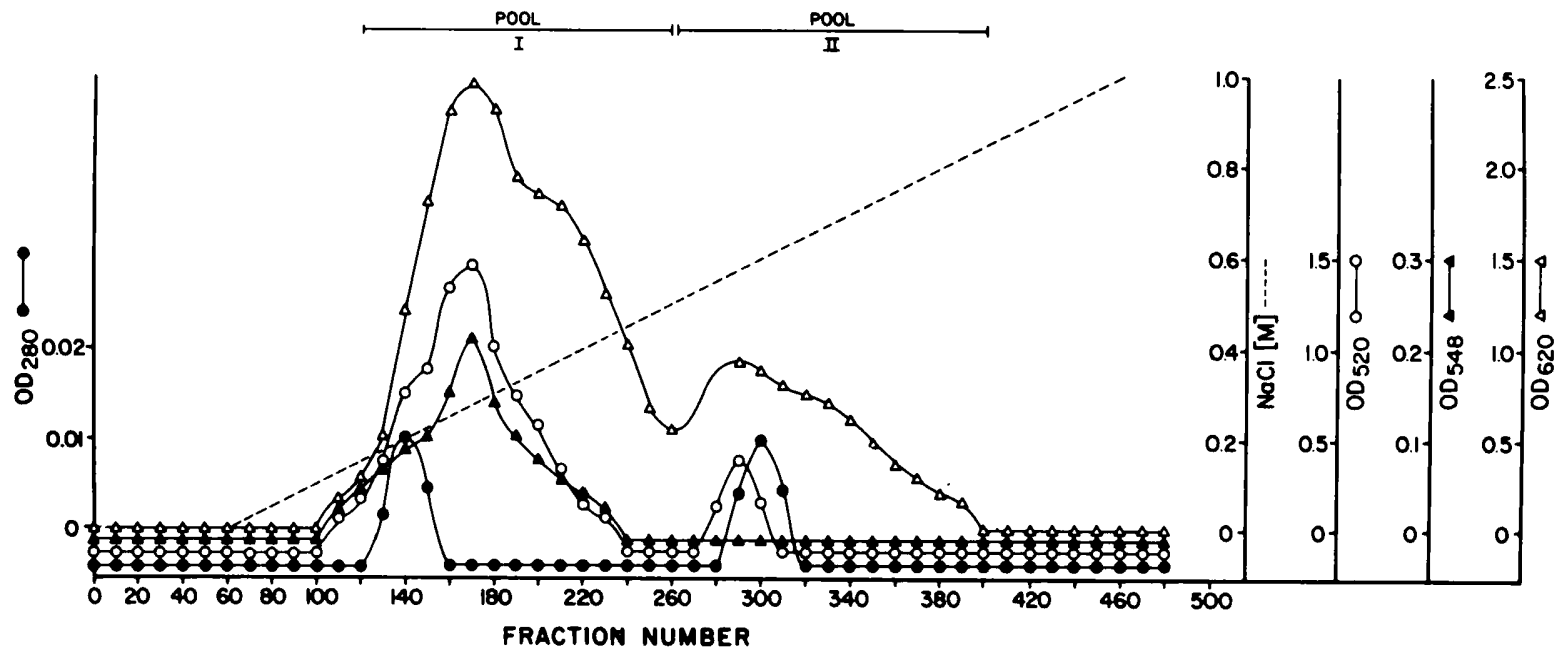

Fig. 1. Elution profile of the ultrafiltration-concentrated extracellular material from $P$. cepacia $61 \mathrm{~g}$ ( $10 \mathrm{~L}$ stationary phase culture) on DEAE-Sephacel. The peaks were eluted with an increasing $\mathrm{NaCl}$ gradient (---) from 0 to $1.0 \mathrm{M}$ in Tris-hydrochloride buffer $(\mathrm{pH} 8 \cdot 0)$. The eluate was continuously monitored for protein by absorbance (OD) at $280 \mathrm{~nm}(\bullet)$ and every fifth tube was assayed for uronic acid $(\circ), \operatorname{KDO}(\Delta)$, and total hexose $(\triangle)$.

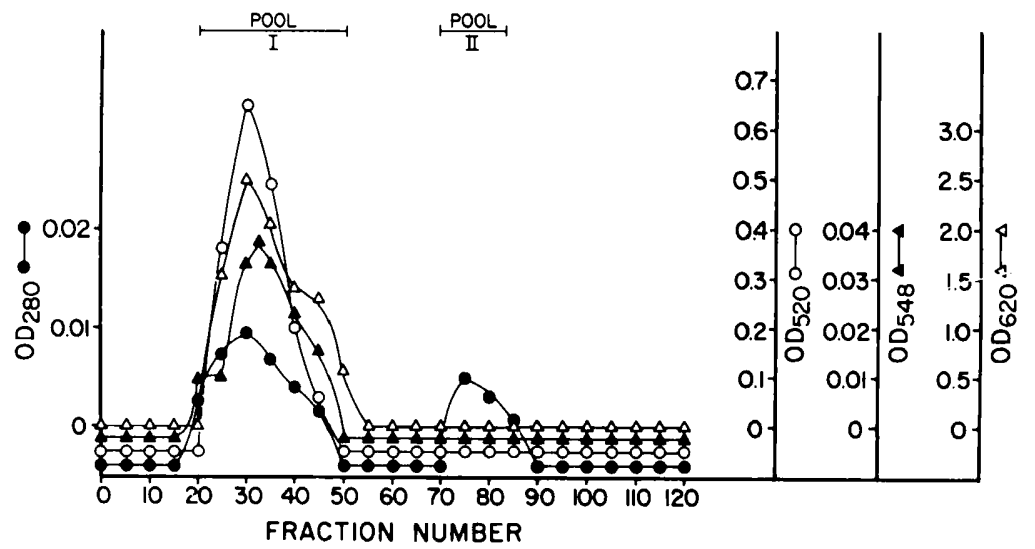

Fig. 2. Elution profile on Sepharose $4 B$ of DEAE-Sephacel pool 1 obtained from the supernatant fluids (10 L) of a stationary phase culture of $P$. cepacia $61 \mathrm{~g}$. All material was eluted with $0.01 \mathrm{M}$ Tris-hydrochloride buffer (pH 8.0). The eluate was continuously monitored for protein by absorbance (OD) at $280 \mathrm{~nm}(\bullet)$, and every fifth tube was assayed for uronic acid (०), KDO ( $\triangle$ ), and total hexose $(\triangle)$. The void volume of this column was $92 \mathrm{ml}$ (tube 20) and the salt volume was $529 \mathrm{ml}$ (tube 115).

nine other $P$. cepacia strains grown to stationary phase in Anwar's defined medium for the presence of KDO. Eight of the ten strains showed no evidence of KDO (data not shown). However, the material from $P$. cepacia $61 \mathrm{~g}$ and one other strain gave a distinctly positive thiobarbituric acid reaction (Osborn, 1963). Spectral analysis indicated that this material absorbed strongly at $549 \mathrm{~nm}$ and was spectrally identical to the purified KDO used as a standard.
Ability of antibodies to ETC to neutralise ETC toxicity and passively protect against $P$. cepacia challenge

Antibody to the ETC can neutralise its toxicity in vivo since antibody to the ETC protected all the experimental animals from death, while all the animals that received ETC + NRS died (table I).

In addition, we sought to determine whether antibodies to the ETC would protect experimental 
Table I. Ability of antibodies to ETC to either neutralise the toxicity of the ETC or protect against live $P$. cepacia challenge or both

\begin{tabular}{llcc}
\hline Source of serum & \multicolumn{1}{c}{ Serum incubation } & $\begin{array}{c}\text { Source of ETC } \\
(500 \mu \mathrm{g} / \mathrm{mouse})^{*}\end{array}$ & $\begin{array}{c}\text { No. of mice dead/ } \\
\text { no. of mice inocu- } \\
\text { lated }(\%)\end{array}$ \\
\hline $\begin{array}{l}\text { Rabbit anti-P. } \\
\text { cepacia } 61 \mathrm{~g} \text { ETC } \\
\text { (IRS) }\end{array}$ & $\begin{array}{l}5 \mathrm{mg} \text { ETC incubated with } \\
1.0 \mathrm{ml} \text { of IRS for } 1 \mathrm{~h} \text { at } 25^{\circ} \mathrm{C}\end{array}$ & $\begin{array}{c}P . \text { cepacia } \\
61 \mathrm{~g}\end{array}$ & $0 / 10(0 \%) \dagger$ \\
$\begin{array}{l}\text { Normal rabbit } \\
\text { serum (NRS) }\end{array}$ & $\begin{array}{l}5 \mathrm{mg} \text { ETC incubated with } \\
1.0 \mathrm{ml} \text { of } \mathrm{NRS} \text { for } 1 \mathrm{~h} \text { at } 25^{\circ} \mathrm{C}\end{array}$ & $\begin{array}{c}\text { P. cepacia } \\
61 \mathrm{~g}\end{array}$ & $10 / 10(100 \%)$ \\
$\begin{array}{l}\text { Rabbit anti-P. } \\
\text { cepacia } 61 \mathrm{~g} \text { ETC } \\
\text { (IRS) }\end{array}$ & $\begin{array}{l}P . \text { cepacia } 61 \mathrm{~g}\left(10^{10} \mathrm{cfu}\right) \\
\text { incubated with } 1.0 \mathrm{ml} \\
\text { of IRS for } 1 \mathrm{~h} \text { at } 25^{\circ} \mathrm{C} \ddagger\end{array}$ & $\ldots$ & $1 / 10(10 \%) \dagger$ \\
$\begin{array}{l}\text { Normal rabbit } \\
\text { serum (NRS) }\end{array}$ & $\begin{array}{l}P . \text { cepacia } 61 \mathrm{~g}\left(10^{10} \mathrm{cfu}\right) \text { incu- } \\
\text { bated with } 1.0 \mathrm{ml} \text { of } \mathrm{NRS} \text { for } \\
1 \mathrm{~h} \text { at } 25^{\circ} \mathrm{C} \ddagger\end{array}$ & $\ldots$ & $10 / 10(100 \%)$ \\
\hline
\end{tabular}

*Purified as described in Materials and methods.

†Significantly different from control values by Fisher's Exact test (Fisher, 1973) $(\mathrm{p}<0 \cdot 005)$.

$\ddagger$ Immediately after serum incubation, these mice received $10^{9} \mathrm{cfu}$ of $P$. cepacia $61 \mathrm{~g}$.

animals against infection with homologous $P$. cepacia. The results of these studies can also be seen in table I. This table shows that antibody to the ETC can passively protect mice against homologous challenge when the challenge organisms are delivered in combination with antibody; $90 \%$ of the animals that received $10^{9} P$. cepacia plus anti-ETC antibody survived, whereas all the animals that received $10^{9}$ P. cepacia + NRS died.

\section{Ability of immunisation by DEAE-Sephacel pool II to protect experimental animals against homologous and heterologous P. cepacia challenge}

Table II shows that mice immunised against the DEAE-Sephacel pool II of $P$. cepacia $61 \mathrm{~g}$ were protected $\left(90 \%\right.$ survival) against $1 \times 10^{9} \mathrm{cfu}$ of $P$. cepacia $61 \mathrm{~g}$. Also, mice immunised against the DEAE-Sephacel pool II of $P$. cepacia $61 \mathrm{~g}$ were protected $\left(80 \%\right.$ survival) against $1 \times 10^{9} \mathrm{cfu}$ of $P$. cepacia K30-6, a heterologous strain. Control mice that were not immunised all succumbed to $1 \times$ $10^{9}$ cfu of $P$. cepacia 61 g or $P$. cepacia K30-6.

\section{Bacteriology and pathology of lungs of rats inoculated with P. cepacia}

In rats inoculated transtracheally with agar beads containing c. $10^{4} \mathrm{cfu}$ of $P$. cepacia $61 \mathrm{~g}$, the number of recoverable organisms rose from the initial inoculum size to $3.7 \times 10^{5}\left(\mathrm{SD} 2 \cdot 1 \times 10^{4}\right) \mathrm{cfu} / \mathrm{lung}$ at day 20. The histopathological picture seen in lungs infected with agar beads containing $P$. cepacia
$61 \mathrm{~g}$ at day 10 was essentially identical to that seen at day 20. Microscopic examination demonstrated both bronchial and parenchymal changes (fig. 3). Purulent exudate and fibrin were present in bronchioles and terminal airways. Dense inflammatory cell infiltrate accumulated in the alveolar spaces and areas of frank necrosis were present.

\section{Pathology of ETC-inoculated lungs}

Microscopic examination of lungs inoculated with ETC demonstrated a progressively increasing accumulation of polymorphonuclear leucocytes in bronchial and alveolar lumina as well as in alveolar septae from 12 to $36 \mathrm{~h}$ (fig. 4). Injury and necrosis of bronchial epithelium, associated haemorrhage and fibrinous exudate was also noted.

\section{Fatty-acid analysis and determination of the component of ETC responsible for toxicity}

As the next step in the characterisation of the ETC, we performed experiments to determine which of the three components (LPS, carbohydrate surface antigen, or protein) present in the ETC was responsible for the observed animal toxicity. Boiling the ETC for $15 \mathrm{~min}$ in $0.01 \mathrm{M}$ Tris-hydrochloride (pH 8.0) or exposure to trypsin ( $1 \mathrm{~g} / \mathrm{L})$ did not alter the toxicity of the ETC. After saponification, however, the ETC was no longer toxic as indicated by i.p. injection into experimental animals. Thus, it appeared that the LPS portion of the ETC was required for the toxicity to be expressed in mice. 
Table II. Ability of immunisation by DEAE-Sephacel pool II (carbohydrate surface antigen) to protect experimental animals against homologous and heterologous $P$. cepacia challenge

\begin{tabular}{lcc}
\hline $\begin{array}{c}\text { Source of carbohydrate } \\
\text { surface antigen* }\end{array}$ & Challenge organisms $\ddagger$ & $\begin{array}{c}\text { No. of mice dead/no. } \\
\text { inoculated }(\%)\end{array}$ \\
\hline P. cepacia $61 \mathrm{~g}$ & P. cepacia $61 \mathrm{~g}$ & $1 / 10(10 \%) \S$ \\
None (control) $\dagger$ & P. cepacia $61 \mathrm{~g}$ & $10 / 10(100 \%)$ \\
P. cepacia $61 \mathrm{~g}$ & P. cepacia $\mathrm{K} 30-6$ & $2 / 10(20 \%)$ \\
None (control) $\dagger$ & P. cepacia $\mathrm{K} 30-6$ & $10 / 10(100 \%)$ \\
\hline
\end{tabular}

*Purified as described in Materials and methods. All immunised mice received $100 \mu \mathrm{g}$ of $P$. cepacia $61 \mathrm{~g}$ DEAE-S pool II delivered i.p. in $1 \mathrm{ml}$ of sterile PBS on days 1 and 8 .

+Control mice received $1 \mathrm{ml}$ of sterile PBS delivered i.p. on days 1 and 8 .

$\ddagger$ On day 15 , a $1 \times 10^{9} \mathrm{cfu}$ challenge of the appropriate organism was injected i.p. into these mice in $1 \mathrm{ml}$ of PBS.

§Significantly different from control values by Fisher's Exact Test (Fisher, 1973) $(\mathrm{p}<0.005)$.

Because the lipid portion of the LPS had been shown to be responsible for its toxicity, a fatty-acid analysis of the ETC of $P$. cepacia $61 \mathrm{~g}$ was attempted by gas chromatography of methyl esters released by acid or base hydrolysis. As can be seen in table III, the major species were hexadecanoic acid and 3-hydroxytetradecanoic acid which, along with $\triangle^{2}$ tetradecanoic acid, accounted for $60 \%$ of the fatty acids by weight. The $\triangle^{2}$-tetradecanoic acid was probably derived from 3-hydroxytetradecanoic acid by dehydration during base hydrolysis.

\section{$L D 50$ value of $P$. cepacia $61 \mathrm{~g}$ and quantitation of in- vivo production of the ETC}

The LD50 value of $P$. cepacia $61 \mathrm{~g}$ when per-

Table III. Fatty acid content of the ETC of Pseudomonas cepacia $61 \mathrm{~g}$

\begin{tabular}{lc}
\hline \multicolumn{1}{c}{ Fatty acid* } & $\begin{array}{c}\text { Amount of fatty acid } \\
(\mu \mathrm{g} / \mathrm{mg} \text { of ETC } \dagger\end{array}$ \\
\hline dodecanoic & $0 \cdot 3(\mathrm{SD} 0 \cdot 1)$ \\
tetradecanoic & $3 \cdot 0(\mathrm{SD} \cdot \cdot 3)$ \\
$\triangle^{2}$-tetradecanoic & $0 \cdot 9(\mathrm{SD} \cdot \cdot 1)$ \\
2-hydroxytetradecanoic & $0 \cdot 4(\mathrm{SD} 0 \cdot 1)$ \\
3-hydroxytetradecanoic & $4 \cdot 7(\mathrm{SD} 0 \cdot 9)$ \\
$\triangle^{9}$-hexadecanoic & $2 \cdot 1(\mathrm{SD} 0 \cdot 7)$ \\
hexadecanoic & $4 \cdot 9(\mathrm{SD} 0 \cdot 4)$ \\
cis-9, 10-methylenehexadecanoic & $1 \cdot 9(\mathrm{SD} 0 \cdot 1)$ \\
unknown & $1 \cdot 3(\mathrm{SD} 0 \cdot 1)$ \\
Total fatty acid & $17 \cdot 5(\mathrm{SD} 1.3)$
\end{tabular}

*Fatty acids released by base hydrolysis accounted for $98 \%$ of the total fatty acids present. No additional fatty acid was present in quantities $>1 \%$ of the total.

tData are reported as mean (SD), $n=3$. formed as described in the Materials and methods in 20-25 g Swiss-Webster mice was $2.89 \times 10^{8} \mathrm{cfu}$. Radial immunodiffusion was performed to quantify the ETC found in the sera of mice infected with 10 LD50 doses of $P$. cepacia $61 \mathrm{~g}$ (table IV). All mice had detectable ETC in their blood when they were killed. Mice had an average of $180 \mu \mathrm{g}$ of ETC per $\mathrm{ml}$ of serum $25 \mathrm{~h}$ after inoculation. ETC values were in the range $50-325 \mu \mathrm{g} \mathrm{ml}$ of serum. Mice that received $10 \mathrm{LD} 50$ values of heat-killed $P$. cepacia $61 \mathrm{~g}$ i.p. did not die of their injection. After $48 \mathrm{~h}$,

Table IV. Quantitation of $P$. cepacia $61 \mathrm{~g}$ ETC in mouse sera by radial immunodiffusion*

\begin{tabular}{ccc}
$\begin{array}{c}\text { Mouse } \begin{array}{c}\text { Time after } \\
\text { no. }\end{array} \\
\text { inoculation }(\mathrm{h})\end{array}$ & ETC $(\mu \mathrm{g} / \mathrm{ml})$ \\
\hline 1 & 20 & 176 \\
2 & 20 & 224 \\
3 & 20 & 80 \\
4 & 22 & 166 \\
5 & 22 & 186 \\
6 & 22 & 50 \\
7 & 22 & 130 \\
8 & 22 & 70 \\
9 & 24 & 224 \\
10 & 24 & 275 \\
11 & 24 & 265 \\
12 & 24 & 196 \\
13 & 24 & 50 \\
14 & 42 & 275 \\
15 & 42 & 325 \\
& &
\end{tabular}

*Samples $(10 \mu \mathrm{l})$ of serum were placed in each well, and plates were incubated for $24 \mathrm{~h}$ at room temperature.

† Mice received 10 LD50 of exponential phase $P$. cepacia $61 \mathrm{~g}$ cells i.p. 
they were killed and we were not able to detect any circulating ETC in their blood.

\section{Virulence enhancement in mice}

Experiments were performed to determine if the ETC from $P$. cepacia $61 \mathrm{~g}$ could enhance the virulence of the homologous organism. The presence of 200,100 , or $50 \mu \mathrm{g}$ of ETC in the peritoneal cavities of mice in concert with viable $P$. cepacia $61 \mathrm{~g}$ lowered the LD50 166-, 10-, and 4.6-fold, respectively.

\section{Discussion}

ETC produced by $P$. cepacia $61 \mathrm{~g}$ appeared to be composed of LPS, a carbohydrate surface antigen and protein and is probably released into the external environment by actively growing cells. Its component parts were not separable by ultrafiltration, ion-exchange (fig. 1), or gel filtration (fig. 2) chromatography. These results are reminiscent of those obtained with a similar compound produced by Klebsiella pneumoniae (Straus et al., 1985; Straus, 1987). The ETC of $P$. cepacia also appeared to contain a uronic acid which is also found in the carbohydrate capsule of $K$. pneumoniae (Straus et al., 1985; Straus, 1987). The significance of this is not clear.

The toxicity is thought to be associated with the LPS moiety, because boiling and protease treatment had no deleterous effect, and only saponification rendered the ETC non-toxic. However, the possibility that the toxicity may be associated with a protein has not been ruled out. It is not clear how the toxicity of the LPS molecule is expressed. When endotoxin enters the blood stream of an experimental animal, the resultant prompt and transient hypertensive state is followed by a progressive severe hypotension (Berry et al., 1982). The availability of blood to important tissues decreases, and death is thought to occur as a result of circulatory collapse. The action of LPS that produces these circulatory changes has not been fully elucidated.

Manniello et al. (1979) reported that there was no detectable KDO in biologically active LPS extracts from two strains of $P$. cepacia subjected to assay by the method of Osborn (1963). This finding was supported by Anwar et al. (1983a) in the isolation and characterisation of the outer membrane of $P$. cepacia. We have used the Osborn method to assay the culture medium of $P$. cepacia $61 \mathrm{~g}$ grown to stationary phase in Anwar's defined medium and have detected material which we believe to be KDO. This material which resulted in a positive thiobarbituric acid reaction (Osborn, 1963), absorbed strongly at $549 \mathrm{~nm}$. It appeared to be spectrally identical to the purified KDO used as a standard. This evidence coupled with the biological activity indicative of endotoxin led us to believe that the LPS of $P$. cepacia $61 \mathrm{~g}$ does in fact contain KDO. However, it should be noted that we examined the culture supernates from a total of ten $P$. cepacia strains for KDO (data not shown) and were able to detect KDO from only two strains. Therefore, it appears that while some strains of $P$. cepacia are capable of producing $\mathrm{KDO}$, the majority of them probably are not.

Analysis of the lipid portion of ETC, the membrane anchoring site of the complex showed the predominance of 3-hydroxytetradecanoic acid and hexadecanoic acid with $\Delta^{9}$-hexadecanoic acid and cis-9, 10-methylene-hexadecanoic acid also present in significant amounts (table III). The unknown fatty acid chromatographed at a position corresponding to a methyleneheptadecanoic acid although it might also be a member of the octadecanoic acid series. The protein portion of the ETC probably plays no role in its toxicity, since treating ETC with trypsin did not effect its ability to kill mice. The role that the carbohydrate surface antigen plays in the toxicity of the ETC is not clear. We have not obtained the LPS moiety free of the carbohydrate surface antigen (fig. 1, pool I). The carbohydrate surface antigen free of the LPS (fig. 1 , pool II) is not toxic in mice. The presence of the carbohydrate surface antigen in the ETC may enhance the toxicity of the LPS moiety by making it more difficult for the animal to excrete it from the body, for example in urine. Compounds such as individual LPS molecules of mol. wt $<20000$ are secreted by the glomerular filtration system with relative ease. The aggregate size of LPS molecules would be hard to predict, especially in vivo. However, a compound with a molecular mass in excess of $2 \times 10^{6}$ (fig. 2) would tend to lodge in the glomerular filtration system, thus setting up a gradient in the blood stream, and maintain the amount of the LPS-containing ETC at very high levels.

The ETC was shown to be lethal when injected i.p. into Swiss-Webster mice in sufficient quantities (395 $\mu \mathrm{g}$ or greater) and sublethal amounts of the ETC enhanced the virulence of the homologous organism. The ETC described here also produced extensive pulmonary pathology in the lungs of specific-pathogen free rats when placed there in the absence of live organisms (fig. 4). The damage produced by sublethal doses of the ETC placed transtracheally in the lungs of rats resulted in a 

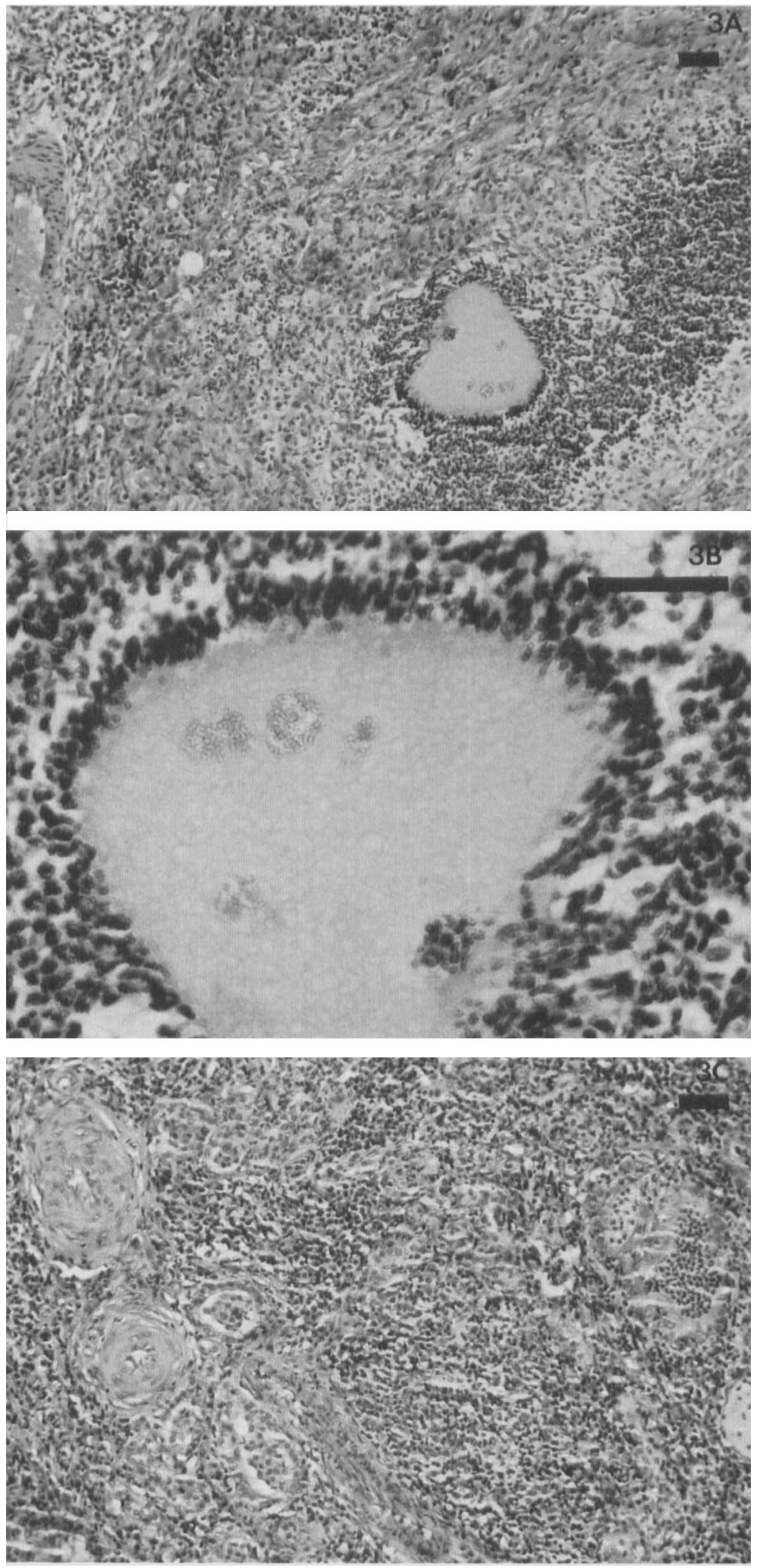

Fig. 3. Photomicrographs of hematoxylin and eosin-stained sections of rat lungs infected with P. cepacia $61 \mathrm{~g}(\mathrm{bar}=100 \mu \mathrm{m})$. (A) Agar bead containing $P$. cepacia lying in bronchial epithelium; suppurative inflammation obscures surrounding area. (B) Higher magnification of (A) demonstrating agar bead rimmed by polymorphonuclear leucocytes. (C) Purulent exudation and fibrin associated with airways and alveolar spaces 20 days after inoculation with $P$. cepacia. 

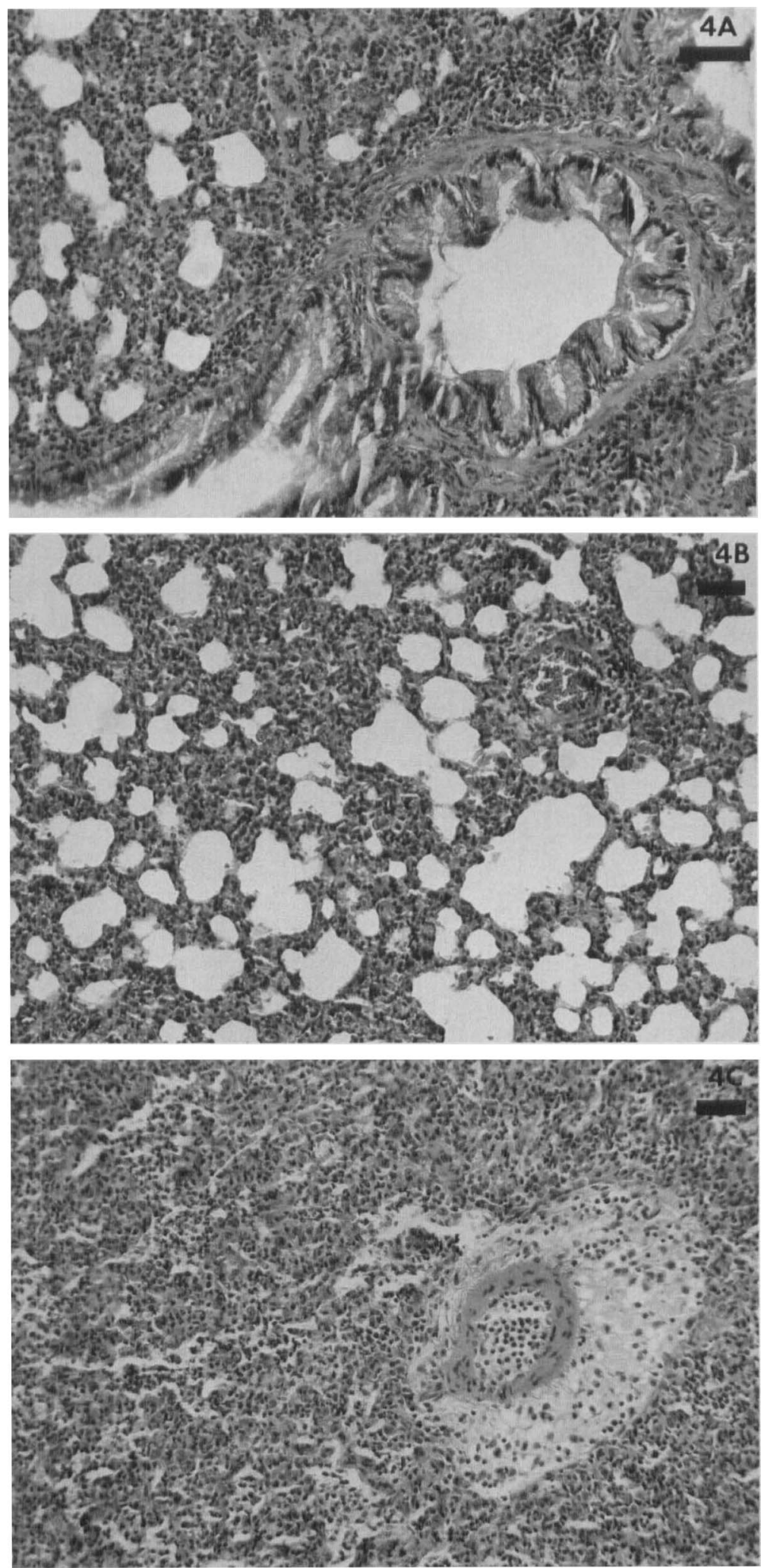

Fig. 4. Photomicrographs of hematoxylin and eosin-stained section of rat lungs inoculated with ETC (bar $=100 \mu \mathrm{m})$. (A) Injury and necrosis of bronchial epithelium and associated suppuration surrounding airway seen $12 \mathrm{~h}$ after inoculation. (B) Progressive parenchyman involvement associated with increasing accumulation of polymorphonuclear leucocytes in bronchial and alveolar lumina $24 \mathrm{~h}$ after inoculation. (C) Frank necrosis seen $36 \mathrm{~h}$ after inoculation, with airway and alveolar consolidation. 
clinical picture even more devastating than the pathology produced by an active $P$. cepacia lung infection (fig. 3). This is in agreement with the observation that $P$. cepacia is relatively avirulent (Lonon et al., 1987) in normal animals. Immunisation with the ETC of $P$. cepacia $61 \mathrm{~g}$ elicited the production of mouse protective antibodies in rabbits. These antibodies neutralised the toxicity of the ETC and protected mice (probably by opsonisation) against challenge with the homologous organism (table I). Immunisation with another extracellular antigen (pool II from DEAE-Sephacel) protected mice against the homologous as well as a heterologous organism. This finding may have great significance if a non-toxic $P$. cepacia antigen is found to induce protection against various heterologous strains. We are currently conducting experiments to determine the extent of this protection.

All 15 mice infected with $P$. cepacia 61 g possessed circulating ETC. Although the values reported here are below the $395 \mu \mathrm{g}$ LD50 for i.p. injection in

\section{REFERENCES}

Anwar H, Brown M R, Cozens R M, Lambert P A $1983 a$ Isolation and characterization of the outer and cytoplasmic membranes of Pseudomonas cepacia. Journal of General Microbiology 129:499-507.

Anwar H, Brown M R, Lambert P A $1983 b$ Effect of nutrient depletion on sensitivity of Pseudomonas cepacia to phagocytosis and serum bactericidal activity at different temperatures. Journal of General Microbiology 129:2021-2027.

Berry L J, Peterson J W, Davis C P 1982 Pathogenesis and nonspecific diseases, P. 192-200. In: Baron S (ed) Medical Microbiology. Addison-Wesley, Menlo Park, CA, USA.

Blessing J J, Walker J, Maybury B, Yeager A S, Lewister N 1979 Pseudomonas cepacia and maltophilia in the cystic fibrosis patient. American Review of Respiratory Disease 119: 262 (abstract).

Blumenkrantz N, Asboe-Hansen G 1973 New method for quantitative determination of uronic acids. Analytical Biochemistry 54:484-489.

Boxerbaum B, Klinger J D 1984 Pseudomonas cepacia bacteremia in cystic fibrosis. Pediatric Research 18:269A (abstract no. 1043).

Burkholder W H, 1950 Sour skin, a bacterial rot on onion bulbs. Phytopathology 40: 115-117.

Cash H A, Woods D E, McCullough B, Johanson W G, Bass J A 1979 A rat model of chronic respiratory infection with Pseudomonas aeruginosa. American Review of Respiratory Disease 119:453-459.

Corey M, Allison L, Prober C, Levison H 1984 Sputum bacteriology in patients with cystic fibrosis in a Toronto hospital during 1970-1981. Journal of Infectious Diseases 149:283.

Fisher R A 1973 The exact treatment of $2 \times 2$ tables. In: Statistical methods for research workers, 14th edn. Hafner Publishing Company, New York, USA, pp 96-97.

Goldman D A, Klinger J D 1986 Pseudomonas cepacia: Biology, mice, it should be noted that there are approximately $2 \mathrm{ml}$ of blood in the average mouse and we did not attempt to quantify the ETC in the tissues. Therefore, had they not been killed, it seems likely that there would eventually have been sufficient ETC in the bodies of these animals to result in their deaths. None of the mice receiving 10 LD50 values of heat-killed $P$. cepacia $61 \mathrm{~g}$ had detectable levels of ETC in their circulatory system. It would appear then that the ETC detected in the blood of mice that received live $P$. cepacia $61 \mathrm{~g}$ is synthesised in vivo, and is not only present in the bacteria themselves. We therefore propose that the ETC produced by $P$. cepacia is responsible for the lethality and extensive pulmonary tissue necrosis associated with pneumonia produced by this organism.

We thank D.J. Hentges for his critical review of this manuscript. This study was supported by a Biomedical Research grant from Texas Tech University Health Sciences Center and a grant from the Canadian Cystic Fibrosis Foundation to D.E.W.

mechanisms of virulence and epidemiology. Journal of Pediatrics 108:806-812.

Isles A et al. 1984 Pseudomonas cepacia infection in cystic fibrosis: an emerging problem. Journal of Pediatrics 104: 206-210.

Loewus F A 1952 Improvement in anthrone method for determination of carbohydrates. Analytical Chemistry 24:219.

Lonon M K, Woods D E, Straus D C 1987 Lipase production by clinical isolates of Pseudomonas cepacia. Abstracts of the Annual Meeting of the American Society for Microbiology K135:p 225.

Lowry O H, Rosebrough N J, Farr A L, Randall R J 1951 Protein measurement with the Folin phenol reagent. Journal of Biological Chemistry 193:265-275.

Manniello J M, Heymann H, Adair F W 1979 Isolation of atypical lipopolysaccharides from purified cell walls of Pseudomonas cepacia. Journal of General Microbiology 112: 397-400.

McCarthy M M, Rourke M H, Spock A 1980 Bacteremia in patients with cystic fibrosis. Clinical Pediatrics 19:746-748.

McKevitt A I, Retzer M D, Woods D E 1987 Development and use of a serotyping scheme for Pseudomonas cepacia. Serodiagnosis and Immunotherapy 1 : 177-184.

McKevitt A I, Woods DE 1984 Characterization of Pseudomonas cepacia isolates from patients with cystic fibrosis. Journal of Clinical Microbiology 19:291-293.

Osborn M J 1963 Studies on the gram-negative cell wall. I. Evidence for the role of 2-keto-3-deoxyoctonate in the lipopolysaccharide of Salmonella typhimurium. Proceedings of the National Academy of Science of the USA 50:499-506.

Reed L J, Muench H A 1938 A simple method of estimating fifty percent endpoints. American Journal of Hygiene 27:493-497.

Rietschel E T, Gottert H, Luderitz O, Westphal O 1972 Nature and linkages of the fatty acids present in the lipid-A 
component of Salmonella lipopolysaccharides. European Journal of Biochemistry 28 : 166-173.

Rosenstein B J, Hall D E 1980 Pneumonia and septicemia due to Pseudomonas cepacia in a patient with cystic fibrosis. Johns Hopkins Medical Journal 147: 188-189.

Straus D C 1987 Production of an extracellular toxic complex by various strains of Klebsiella pneumoniae. Infection and Immunity 55:44-48.

Straus D C, Atkisson D L, Garner C W 1985 Importance of a lipopolysaccharide-containing extracellular toxic complex in infections produced by Klebsiella pneumoniae. Infection and Immunity 50:787-795.

Tablan O C et al. 1985 Pseudomonas cepacia colonization in patients with cystic fibrosis: Risk factors and clinical outcome. Journal of Pediatrics 107:382-387.

Tablan O C et al. 1987 Colonization of the respiratory tract with Pseudomonas cepacia in cystic fibrosis. Risk factors and outcomes. Chest 91 : 527-532.

Thomassen M J, Demko C A, Doershuk C F, Stern R C, Klinger J D 1986 Pseudomonas cepacia: decrease in colonization in patients with cystic fibrosis. American Review of Respiratory Disease 134: 669-671.

Thomassen M J, Demko C A, Klinger J D, Stern R C 1985 Pseudomonas cepacia colonization among patients with cystic fibrosis; a new opportunist. American Review of Respiratory Disease 131 : 791-796. 